\title{
Ocular Exploration in the Diagnosis and Follow-Up of the Alzheimer's Dementia
}

\author{
Elena Salobrar-Garcia1 • Rosa de Hoz ${ }^{1,2} \bullet$ Ana I. Ramírez1,2 • \\ Juan J. Salazar ${ }^{1,2} \bullet$ Pilar Rojas $^{1,3} \bullet$ Inés López-Cuenca ${ }^{1} \bullet$ \\ Jose Fernández-Albarral ${ }^{1} \bullet$ José M. Ramírez ${ }^{1,4}$ \\ ${ }^{1}$ Instituto de Investigaciones Oftalmológicas Ramón Castroviejo, Universidad Complutense \\ de Madrid, Madrid, Spain; ${ }^{2}$ Facultad de Óptica y Optometría, Universidad Complutense \\ de Madrid, Madrid, Spain; ${ }^{3}$ Hospital Universitario Gregorio Marañón, Madrid, Spain; \\ ${ }^{4}$ Facultad de Medicina, Universidad Complutense de Madrid, Madrid, Spain
}

Author for correspondence: José M. Ramírez, Instituto de Investigaciones Oftalmológicas Ramón Castroviejo, Facultad de Medicina, Universidad Complutense de Madrid. Spain. Email: ramirezs@med.ucm.es Doi: http://dx.doi.org/10.15586/alzheimersdisease.2019.ch10

\begin{abstract}
The retina is part of the central nervous system (CNS), and therefore, in Alzheimer's disease (AD), retinal and optic nerve degeneration could take place. This degeneration leads to neurofunctional changes that can be detected early and followed up throughout the evolution of the disease. As opposed to other CNS structures, the eye is easily accessible for in vivo observation. Retinal organization allows for the identification of its different neurons, and in consequence, detection of minimal changes taking place during neurodegeneration is possible. Functional vision studies performed on $\mathrm{AD}$ patients in recent years have shown how visual acuity, contrast sensitivity, color vision, and visual integration vary with the progression of neurodegeneration. The development of optical coherence tomography in ophthalmology has meant a breakthrough in retinal exploratory techniques, allowing the obtention of high-resolution images using light. This technique enables retinal analysis in the earliest stages of $\mathrm{AD}$, being considered as a biomarker of neuronal damage. Given AD's high prevalence and its expected increase, it is important to
\end{abstract}

In: Alzheimer's Disease. Thomas Wisniewski (Editor), Codon Publications, Brisbane, Australia. ISBN: 978-0-646-80968-7; Doi: http://dx.doi.org/10.15586/alzheimersdisease.2019

Copyright: The Authors.

License: This open access article is licensed under Creative Commons Attribution 4.0 International (CC BY 4.0). https://creativecommons.org/licenses/by-nc/4.0/ 
perform easy tests that cause minimal discomfort to the patients at a low cost while offering abundant information on the stage of the disease.

Keywords: Alzheimer's disease; biomarker; neurodegeneration; retina; visual system

\section{INTRODUCTION}

Alzheimer's disease (AD) is recognized by the World Health Organization as a global public health priority. AD is the single principal cause of dementia, between 50 and $75 \%$, and is primarily a condition of aging, roughly doubling in prevalence every 5 years after age 65 (1). The incidence of AD increases with age, and the prevalence is growing as a result of the aging of the population (2); however, there are no disease-modifying therapies currently available, and none have been successful in late-stage clinical trials (3).

Late-onset AD is likely to be driven by a complex interplay between genetic and environmental factors, implicating inflammatory, cholesterol metabolism and endosomal-vesicle recycling pathway (4) and the presence of the $\mathrm{APOE}+4$ allele (5). In addition, AD is frequently associated with vascular dysfunctions and inflammation (6). In particular, it is now recognized to play a key role in AD pathogenesis the microglial activation in response to amyloid deposition (7).

The basis of AD has not been fully elucidated. However, the progressive accumulation of $\beta$-amyloid $(A \beta)$ plaques and abnormal forms of phosphorylated tau (tau tangles) within and outside of neurons and neuroinflammation, both of which could lead to neuronal loss and synaptic dysfunction (8), are considered to be the neuropathological hallmarks (9-11).

The "amyloid cascade hypothesis" (12) is based on the progressive deposition of fibrillar $A \beta$ as diffuse plaques, which activates an inflammatory response, altered ion homeostasis, oxidative stress, and altered kinase/ phosphatase activity, leading to the formation of NFTs and widespread synaptic dysfunction and neuronal death (13). Recently, it has been demonstrated that an $A \beta$ plaque environment can accelerate the templated spread of tau pathology $(14,15)$.

Hyperphosphorylation of tau has numerous pathogenic effects. It reduces tau's affinity for microtubules and increases its possibility to aggregate and fibrillize (16). This impact leads to weakening of microtubules with consequent axonal transport failure and neurodegeneration (15).

In the past decade, remarkable advances have been made in diseasespecific biomarkers based on the detection of amyloid or neurodegeneration. With the knowledge that the pathological changes occur years previous to symptoms, the arrival of biomarkers of $A \beta$ and tau pathology, and nuclear imaging measures of atrophy, diagnostic criteria have evolved to allow for the diagnosis to be made both earlier and with increased molecular specificity.

These biomarkers not only enable the diagnosis of $\mathrm{AD}$ in the stage of dementia but also beforehand, in the prodromal stages of AD. However, these biomarkers are not applicable as population-wide screening tools because they are invasive, not easily applicable and expensive. 


\section{EYE AND BRAIN: SYMBIOTIC RELATIONSHIP}

Over the last few decades, in neurodegenerative diseases of the central nervous system (CNS), the importance of ophthalmic examination has reportedly increased. It is not surprising that the retina, as an extension of the CNS, is impaired in patients with CNS degeneration (17). The eye has unique physical structures and is host to specialized immune responses similar to those in the brain and spinal cord (18-20). In fact, abnormal results were found in $\mathrm{AD}$ patients in test exploring visual processing/visual pathways and also in those examining the retina (17).

The neuroinflammatory changes could be detected using a routinely diagnostic technique used in ophthalmology, the optical coherence tomography (OCT). OCT allows to see the anatomic detail of pathological changes in the retina and optic nerve. Changes in OCT measurements have been used to study the course of neurodegenerative diseases such AD (21-25), suggesting that the data compiled may be useful as a biomarker in diagnosing and treating neurodegenerative disease.

The retina is made up of specialized neuron layers that are interconnected via synapses (photoreceptors, bipolar cells, horizontal cells, amacrine cells, interplexiform cells and ganglion cells) $(18,26)$. In the eye, the light that enters is captured by the photoreceptor cells in the outer retina, initiating a cascade of neural signals that finally reach the retinal ganglion cells (RGCs), whose axons form the optic nerve. These axons project to the lateral geniculate nucleus in the thalamus and to the superior colliculus in the midbrain, whose information is then transmitted to specialized visual processing centers in the brain that provide a perception of the world.

The first study, showing postmortem anomalies in the optic nerve of patients with $\mathrm{AD}$, demonstrated not only widespread axonal degeneration but also a reduction in the number of RGC and the thickness of nerve fiber layer (NFL), with a 25\% decrease of ganglion cell layer (GCL) (27-29). More recent OCT studies also found a decrease in the thickness of inner retinal layers (NFL and GCL) (30-41).

The presence of $A \beta$ plaques in GCL could explain the RGC degeneration in the $A D$ course $(19,27,42)$. In fact, it has been demonstrated that most of the $A \beta$ plaques deposited in the retina are located in the GCL $(43,44)$. Deposits of A $\beta$ trigger a neurotoxic effect in the RGC, inducing apoptosis (45). This apoptosis is dose- and time-dependent (45). Some pieces of evidence showed that A $\beta$ expression is greater in the central retina than in the periphery of the eye of an $\mathrm{AD}$ mouse model (46). As in the brain, $A \beta$ deposits in the retina have the classical plaque structure, forming clusters along the blood vessels (47). A $\beta$ accumulations were located inside and around melanopsin retinal ganglion cells (mRGC) and more evident in the superior quadrant of the retina (47).

In the last few years, it was found that mRGCs also showed a significant loss in postmortem AD retinas (47). These cells represent the $1-2 \%$ subpopulation of RGC that are intrinsically photosensitive $(47,48)$. The mRGC send ambient light information to the hypothalamus nucleus via the retinohypothalamic tract (48), regulating circadian rhythms, pupil size, sleep alertness, and pineal melatonin synthesis (49-51). This mRGC loss could contribute to circadian dysfunction in $\mathrm{AD}$ (47). Indeed, its presence in the early stages of $\mathrm{AD}$ of circadian dysfunction was postulated as the worst prognostic value in $\mathrm{AD}(47)$. 
All these retinal changes could be responsible, in part, for the visual deficit that occurs in AD patients. The acetylcholine decrease is also characteristic of this disease, and therefore contributes to the visual deficit that occurs in $\mathrm{AD}$ patients because acetylcholine is essential for the correct visual process of healthy retinas (52).

\section{VISUAL FUNCTIONAL TESTS IN THE EXPLORATION OF AD}

Aging affects visual function because light transmission diminishes inside the eye, whereas the scattering of light increases. With age, there is not only a decrease in the density of photoreceptors in the retina, but there is also less efficiency in phototransduction and photopigment regeneration (53). In addition to aging, visual processing is affected in $\mathrm{AD}$ patients. The brain's visual areas are involved in $\mathrm{AD}$ pathology (in the dorsal and ventral regions), worsening the perception of movement; angular and color discrimination; and form and face identification (54-60). There are several tests such as the visual acuity test, and the contrast sensitivity and color vision test to explore this visual processing in the ophthalmology practice.

\section{Visual acuity}

Visual acuity (VA) is a measure of the spatial resolution of the visual system to detect and discriminate an object. In patients with $\mathrm{AD}$, it is very important to choose the correct VA test. It was demonstrated that VA tests present better values if the letters are isolated (61).

\section{Contrast sensitivity and color vision}

The contrast sensitivity (CS) test assesses the capacity of the visual system to distinguish an object from the background in which it is placed. The CS test allows us to ascertain the integration of the information of the ganglion cells receptor field and their cortical processes. CS is measured by a threshold curve in which the spatial frequencies examined are depicted. Color vision is an illusion created by the interactions of the neurons in our brain. It is intimately linked to the perception of form where color facilitates detecting borders of objects (62). Parvoand magnocellular ganglion cells are located in the GCL and lead to two different visual pathways that identify color and contrast (63). Parvocellular ganglion cells are smaller and more numerous than other retina ganglion cells, with smaller receptor fields located in the macular retinal area. They give rise to the parvocellular visual pathway, specialized in pattern identification and color; and it is most sensitive to high spatial frequency (51). The magnocellular pathway originates in magnocellular retina ganglion cells, which are larger and more numerous, and have larger receptor fields that are more sensitive to low spatial frequencies (63). There is a third type of ganglion cell that is called koniocellular, which receives information from short wave cones. Koniocellular cells are also sensitive to blueyellow tones $(64,65)$. CS is a really important visual function. Even several studies showed that a CS loss is the best predictor of the ability of elders to perform daily life activities $(66,67)$. 


\section{Visual fields}

The visual field (VF) refers to the total space in which objects can be seen in the side (peripheral) vision as your eyes are focused on a central point. The fovea, where the cone photoreceptor density is at its highest, is the area of greatest sensitivity. The visual sensitivity comes down further from the fovea. Traditional perimetry is carried out under photopic conditions, and therefore, rod photoreceptors do not contribute to the visual field (68). The normal visual field extends to approximately $60^{\circ}$ nasally, $90^{\circ}$ temporally, $60^{\circ}$ superiorly and $70^{\circ}$ inferiorly. In the area of the optic nerve head, temporal part of the VF, exists a blind spot that indicates an area with no photoreceptors (69).

\section{Visual integration}

Identifying a visual stimulus requires not only physical input analysis but also the contact between the neuronal representations of the stimulus and the memories that the perceivers have accumulated through their life experiences with the objects. Object identification arises from the dynamic interaction between a sensorial/physical process (upstream processing) and a cognitive process (downstream processing). Spatial frequency is an important physical property of the image. The extraction of visual sensory characteristics follows a course to a fine processing scheme where the low spatial frequency represents the overall information about the shape and orientation of the stimulus, while the high spatial frequency corresponds to the configuration information and fine details (70-75).

\section{OPHTHALMOLOGICAL METHODS FOR RETINAL ANALYSIS}

Over the past decade OCT has evolved as one of the most important tests in ophthalmic practice. It is a non-invasive imaging technique that provides highresolution, cross-sectional images of the retina.

\section{Optical coherence tomography}

OCT was first demonstrated for cross-sectional retinal imaging in 1991 by a Massachusetts Institute of Technology (MIT) team (76). OCT synthesizes crosssectional images from a series of laterally adjacent depth-scans giving a noninvasive clinical tool to evaluate the structural anatomy and the evaluation of the integrity of the retina.

\section{Optical coherence tomography angiography}

Optical coherence tomography angiography (OCTA) is a promising new method for visualizing the retinal vasculature and choroidal vascular layers. A key advantage of OCTA over traditional fluorescein angiography is that it provides depthresolved information without contrast. The basis of OCTA is to repeatedly scan a region and then examine the resultant images for changes. Stationary tissue 
structures will show little change, whereas moving structures, such as blood flowing through vessels, can show changes between images. Contrast is generated based on the difference between moving cells in the vasculature and the static surrounding tissue. This imaging technique can be performed in patients for whom fluorescein angiography or indocyanine green angiography may not be indicated (77). OCTA is clinically used as an en face imaging modality, which is generated by summarizing the flow information within the depth range encompassed by the current scheme. This scheme subdivides the retinal circulation into two plexuses and choroidal circulation into two slabs. Angiograms, which are similar to fluorescein angiography or indocyanine green angiography, are also produced (78).

\section{FUNCTIONAL CHANGES IN AD}

Nowadays, it is known that, in AD, in addition to altering brain structures, the involvement of the different regions of the visual system also occurs, with a manifestation of distinct symptoms and signs that can be detected by clinical history and ophthalmological studies.

VA has proven to be a controversial test in AD. Studies have not found an alteration in AD patients (79-86), and others have found VA loss and linked them to visual hallucinations $(87,88)$ (Table 1$)$. Moreover, these alterations of VA are

\section{TABLE 1 Eye changes in AD patients}

\section{References}

\begin{tabular}{lll}
\hline Visual alterations & & \\
& Visual acuity & 87,88 \\
& Contrast sensitivity & $82,84,85,90-102,103,104$ \\
& Visual field & $105-109$ \\
& Color vision & $58,84,93,110,113-116$ \\
& Visual integration & 93,117 \\
& & \\
Structural alterations & Retinal A 3 deposition & $19,27,42-47$ \\
& Optic nerve & $27-29$ \\
& Macular thickness & \\
& Inner retinal layers & $30-41,138,140-145$ \\
$\quad$ Outer retinal layers & 135 \\
& Peripapillary thickness & $21,24,30-38,120-127$ \\
& Retinal vascularization & $148-150$ \\
& Choroid thickness & $125,148,151-153$
\end{tabular}

AD: Alzheimer's disease; $A \beta$ : beta-amyloid 
related to difficulties in writing and reading (89). On the other hand, recent studies have found that CS testing is a more sensitive tool than VA testing to identify the subclinical impairment of visual function $(90,91)$. CS precedes the development of dementia at 10 years of the longitudinal follow-up in a well-phenotyped, prospective, community-based cohort $(90,91)$. It has been shown that the CS function is affected in $\mathrm{AD}$ patients. The impairment ranges from a reduction in all spatial frequencies $(85,92-99)$ to a greater decline in high $(92,93,98,100)$ or low spatial frequencies $(82,84,101,102)$. Such discrepancies in the affected frequencies could be due to differences among the CS test used as well as the patients included in the studies $(17,66)$. Recent works show that CS is the main manifestation during the initial disease stage. There is a progressive impairment throughout the disease course $(93,103,104)$ (Table 1). CS impairment in AD has consequences for cognitive abilities and daily functions, given that the most affected spatial frequencies are the higher frequencies corresponding to macular function (17). The presence of reduced CS years before the clinical onset of dementia suggests that this association is not simply a consequence of later stage dementia. Furthermore, reduced CS can precede the clinical onset of cortical or subcortical dementia neurodegeneration (90).

Visual field test requires significant cooperation from the patient. Therefore, the reports of VF and $\mathrm{AD}$ are scarce, and most are case reports $(17,68)$. However, it has been observed that decreased VF sensitivity correlated with cognitive impairment. A large prospective study of threshold VF perimetry in patients with probable $\mathrm{AD}$ demonstrated that the most common VF abnormality was bilateral inferior constriction of the VF in an arcuate-like pattern $(105,106)$. AD patients underwent a diffuse sensitivity loss and defects that involved the central field. In $39 \%$ of $\mathrm{AD}$ patients, the density of plaques and tangles was greater in the cuneal compared with lingual gyri, supporting the theory that cortical disease is responsible for the VF loss (105). Recent findings show that the side of the homonymous defect is predicted by lateralized occipital atrophy (107-109) (Table 1).

Another manifestation of $\mathrm{AD}$ is the fluctuations in color perception, which are mainly errors in color recognition due to the involvement of the parvocellular pathway (110).

In the color perception, some studies using the Farnsworth test and Ishihara test found no differences between AD patients and control group $(96,111,112)$. On the other hand, some tritan-axis defects were found, showing a correlation with the cognitive decline $(58,84,93,113,114)$. The discrepancy in the results of both studies may be due to the fact that each study used a different color vision method. A recent investigation showed that the Ishihara color vision test could discriminate between AD and vascular dementia (115). The Ishihara test may involve dorsal cortical pathways that extend from the occipital to the parietal lobes. In the Ishihara test, the patients have to identify a number occulted in a pattern made up of small color forms with different tones. AD patients usually present simultagnosia caused by an occipitoparietal dysfunction, and therefore, they cannot recognize the pattern that is presented in the Ishihara test. The problem does not lie in the color sense, but in the inability to reconstruct the pattern (115). Using the Farnsworth-Munsell 100 hue test, a significantly decreased color discrimination was found in $\mathrm{AD}$. In addition, the number of color discrimination errors was inversely related to Mini-Mental State Examination scores (MMSE) (110). Some studies using the Farnsworth color testing methods, not influenced 
by dorsal stream dysfunction, suggest that $\mathrm{AD}$ patients tend to have tritan color defects $(58,93)$ while others have found a protanomaly (116) (Table 1).

The perception digital test (PDT) is a sensitive method in mild AD patients developed for evaluating their visual-perception disorders (117). The test is designed to assess the visual recognition of familiar situations. PDT has a significant correlation with the cognitive decline of the $\mathrm{AD}$ patient, indicating that patients with mild AD have significantly more failures in PDT than controls $(93,117)$ (Table 1).

\section{STRUCTURAL CHANGES IN AD}

The retinal nerve fiber layer (RNFL), RGC and inner retinal layers are considered indirect biomarkers of the CNS, allowing the prediction of brain pathology in patients suffering from different neurological diseases $(118,119)$. Many studies focus on the thickness of segmented peripapillary RNFL (superior, inferior, nasal, and temporal) in patients with AD comparing them with controls. Some works showed a decrease in the peripapillary RNFL thickness in all areas (30, 31, 34, 36-38). However, others authors found that the peripapillary RNFL thinning occurred in the inferior and superior regions $(35,39,40)$, while other works demonstrated that peripapillary RNFL thinning appeared only in the superior region (120-124). Some studies reported thinning in the RNFL associated with a progressive cognitive decline $(21,24,123,125,126)$ (Table 1$)$. The variance in peripapillary RNFL thickness reported in AD might be due to differences in disease progression among patients studied since patients with greater peripapillary region alteration were those with a more advanced stage of $\mathrm{AD}$. In any case, thinner peripapillary RNFL indicates fewer RGCs in AD, which confirmed the differences in OCT measurements in AD patients (127). The loss of RGCs is matched with the pathologic cascade hypothesis in $\mathrm{AD}$, which affects both the cerebral neuron and the RGCs in the retina (36). This whole peripapillary RNFL controversy is the result of studies based on small size samples and important methodological heterogeneity $(37,128-130)$. In line with this hypothesis, pattern electroretinography showed a decrease in their wave response, suggesting that RGCs are directly involved in AD (38, 92, 131-133).

Some authors did not show any statistical significance with respect to the macular outer retinal thickness analysis between the neurodegenerative disease and control groups (134). However, other studies in the context of early AD observed a loss in the outer nuclear layer that could suggest retrograde transsynaptic degeneration (135). In AD, most of the studies have been done with OCT, and they have focused on the inner retinal layers, whereas less attention has been devoted to the outer retinal layers. The discrepancy in results could be due to technical variability, examination time and OCT interpretation $(129,136,137)$. By using human postmortem tissue in the eyes of severe $\mathrm{AD}$ patients with confirmed neuropathology, different patterns of thinning in the superior-nasal and superior-temporal regions of the retina relative to the optic nerve have been found. Also, they found a gradient of thickness reduction whereby thinning was greatest for the inner layers of the retina, followed by the outer layers of the retina (138). This thickness profile matches the distribution of the retinal $A \beta$ deposits in the mid- and 
far-periphery of the superior quadrants of these tissues as previously demonstrated $(19,28,29,47,139)$.

In the last few years, some studies focusing on the analysis of patients with mild cognitive impairment (MCI) found a thinning in the macular inner layers (140). By contrast, a macular volume increase was found in MCI compared with controls in others works (141). This finding could be explained as a possible inflammation and gliosis prior to neurodegeneration.

\section{CHANGES IN THE EARLY AD AND THEIR PROGNOSTIC VALUE IN THE DETECTION AND FOLLOW-UP}

In the most incipient AD stages, the macular RNFL thickness and total macular volume measured by OCT have better prognostic values in mild AD patients than in healthy subjects. The thickness of the inner superior macula seems to have the highest diagnostic value in early $\mathrm{AD}$ neurodegeneration. Possibly, the macular area is the first affected area of the retina, which may be due to the large number of ganglion cells in this retinal area $(21,24)$. Other studies have primarily assessed retinal thickness changes in the macula to explain the visual symptoms experienced by AD patients (138). The earliest detectable structural retinal change associated with $\mathrm{AD}$ is suggested to be a decrease in macular RNFL volume, and it is related to neocortical $A \beta$ accumulation in the very early $A D$ (135). In healthy eyes, the macular region of the retina is physiologically very active, and this hyperexcitation might be diminishing in the preclinical stage of AD (28). In support of this theory, postmortem histological studies have found pathological alteration of RGC in the macular region in $\mathrm{AD}$ patients $(28,47)$. In a meta-analysis of 17 studies comparing $\mathrm{AD}$ patients with healthy controls and in five studies comparing individuals with MCI with controls, there were significant decreases in the thickness of the macular region in all four quadrants compared to controls, thus suggesting that the degenerative process affects the entire macular region (130). Another work, using a multivariate regression model show the existence of specific areas of thickening, interspersed with areas of thinning in the macula of AD and $\mathrm{MCI}$ patients. This finding supports the idea that inner retinal layers may be suffering dynamic changes during the course of AD progression (142). The retinal thickening in $\mathrm{MCI}$ was attributed to gliosis preceding neuronal loss and atrophy of the axonal projections in the RNFL (143). This theory has been supported by histopathology work, suggesting that gliosis precedes human AD pathology in the brain $(144,145)$. However, other studies in OCT suggested that the outer retinal thickness did not show any statistical significance between the neurodegenerative disease groups and controls (134). Other authors consider that many other findings have been described such as a reduction in macular volume, RGC layer thickness, choroid thickness and some vascular alteration. These results might be promising biomarkers for dementia staging and AD progression $(146,147)$.

In recent years, thanks to the development of the OCTA, several studies analyzed the retinal vascularization and the choroid. Most of the studies, published in moderate $\mathrm{AD}$, have found a loss of the retinal vascular density in the macular area with slower blood flow and an increase in the foveal avascular 
A. Visual Acuity

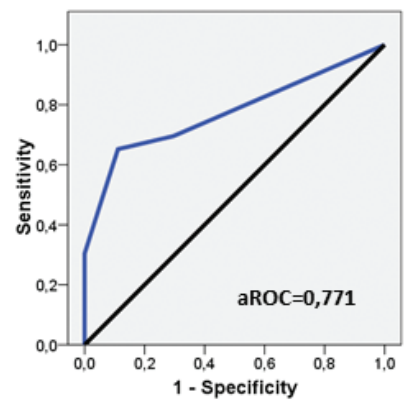

C. Color Vision

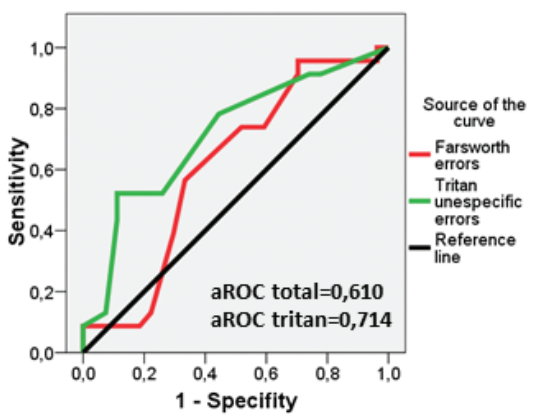

\section{E. Fovea/ Macular volume}

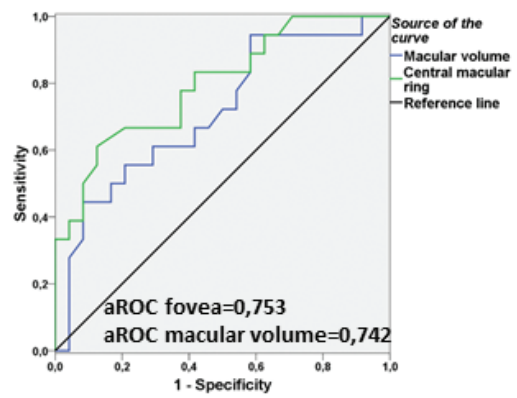

B. Contrast Sensitivity

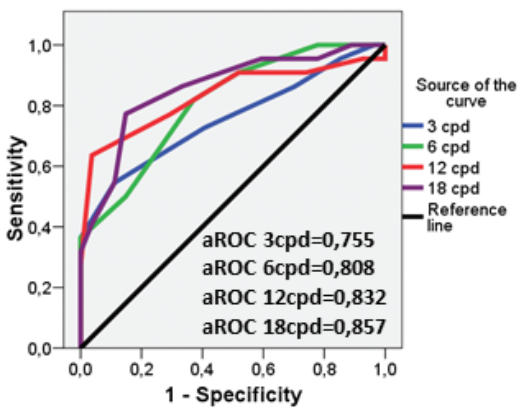

D. Perception Digital Test

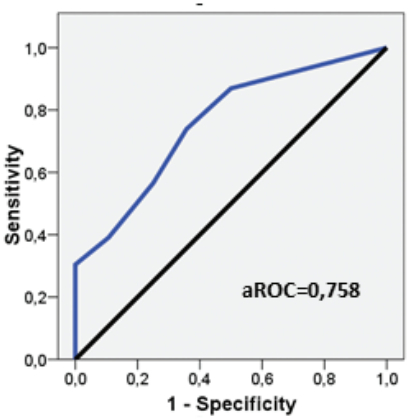

F. Inner macular quadrants

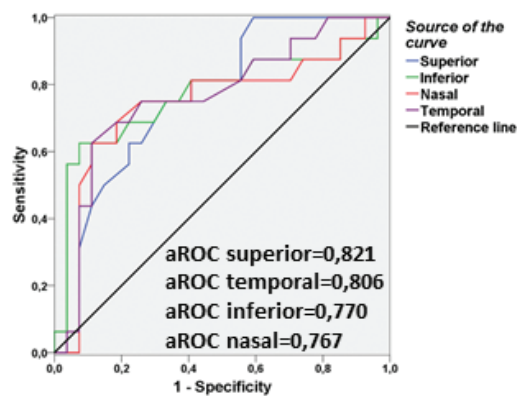

Figure 1 Areas under the ROC curves of the psychophysical tests (A-D) and macular OCT (E-F) in discriminating between mild AD patients and control subjects. (A) Visual acuity (dec),

(B) contrast sensitivity, (C) Rue 28-hue color test, (D) perception digital test, (E) fovea and macular volume, and $(\mathrm{F})$ inner macular quadrants. Modified from (A-D) Salobrar-Garcia et al., 2015 (93) and (E-F) Garcia-Martin et al., 2014 (21). 
zone (148-150). All these parameters presented a correlation with the disease stage (148). In the same way, a thinning of the choroid, measured by OCT, was also found (125, 148, 151-153) (Table 1).

All these changes could be explained as a consequence of the amyloid angiopathy, which occurs in $\mathrm{AD}$, in which amyloid deposits formed in the walls of the blood vessels. This process resulted in an ocular vascular occlusion and the diminishing of blood flow (120, 148, 149, 154).

It is possible that retinal AD biomarkers can only be obtained after having integrated various of the already cited biomarkers, which include both neuroretinal (such as RFNL, GCL, macular thickness) and retinovascular parameters (vessel morphology among others), in a composite biomarker (128).

The analysis of the ophthalmological tests prognostic value of AD showed that VA, CS, color perception, and visual integration (93) have a significant predictive value in early AD disease (Figure 1). The CS is the best predictive test in the diagnosis of the AD with an aROC between 0.857 and 0.755 (93), while the aROC curves of the OCT showed the best prognostic value is found in the macular area with values of $r=0.821$ (21) (Figure 1 ). The focus must be centered on these tests to see the visual changes in the AD disease.

\section{CONCLUSION}

In conclusion, several alterations have been shown in the visual perception and the retinal structure in the eyes of AD patients, even in the earliest stages. The VA, CS, color perception, and visual integration tests, as well as macular OCT, have been altered in the early stages. When the disease progresses in the eyes of moderate $\mathrm{AD}$ patients, retina alteration reaches the peripapillary area, showing the progression of neurodegeneration in the eye.

Conflict of interest: The authors declare no potential conflicts of interest with respect to research, authorship, and/or publication of this chapter.

Copyright and Permission Statement: We confirm that the materials included in this chapter do not violate copyright laws. All original sources have been appropriately acknowledged and/or referenced. Where relevant, appropriate permissions have been obtained from the original copyright holder(s).

\section{REFERENCES}

1. Lane CA, Hardy J, Schott JM. Alzheimer's disease. Eur J Neurol. 2017 Jan;25(1):56-67. http://dx.doi. org/10.1111/ene.13439

2. Alzheimer's Association. 2017 Alzheimer's disease facts and figures. Alzheimers Dementia. 2017;13(4):325-73. http://dx.doi.org/10.1016/j.jalz.2017.02.001

3. Bachurin SO, Bovina EV, Ustyugov AA. Drugs in clinical trials for Alzheimer's disease: The major trends. Med Res Rev. 2017 Sep;37(5):1186-225. http://dx.doi.org/10.1002/med.21434

4. Karch C, Goate AM. Alzheimer's disease risk genes and mechanisms of disease pathogenesis. Biol Psychiatry. 2015 Jan 1;77(1):43-51. http://dx.doi.org/10.1016/j.biopsych.2014.05.006 
5. Martínez-Lazcano JC, Boll-Woehrlen MC, Hernández-Melesio MA, Rubio-Osornio M, SánchezMendoza MA, Ríos C. Radicales libres y estrés oxidativo en las enfermedades neurodegenerativas. Mensaje Bioquim. 2010;34:43-59.

6. Dudvarski Stankovic N, Teodorczyk M, Ploen R, Zipp F, Schmidt MHH. Microglia-blood vessel interactions: A double-edged sword in brain pathologies. Acta Neuropathol. 2016 Mar 28;131(3):347-63. http://dx.doi.org/10.1007/s00401-015-1524-y

7. Escott-Price V, Sims R, Bannister C, Harold D, Vronskaya M, Majounie E, et al. Common polygenic variation enhances risk prediction for Alzheimer's disease. Brain. 2015 Dec;138(Pt 12):3673-84. http://dx.doi.org/10.1093/brain/awv268

8. García-Ospina G, Jímenez-Del MR, Lopera F, Vélez-Pardo C. Neuronal DNA damage correlates with a positive detection of c-Jun, nuclear factor kB, p53 and Par-4 transcription factors in Alzheimer's disease. Rev Neurol. 2003;36(11):1004-10. http://dx.doi.org/10.33588/rn.3611.2002533

9. Jan AT, Azam M, Rahman S, Almigeiti AMS, Choi DH, Lee EJ, et al. Perspective insights into disease progression, diagnostics, and therapeutic approaches in Alzheimer's disease: A judicious update. Front Aging Neurosci. 2017;9:356. http://dx.doi.org/10.3389/fnagi.2017.00356

10. Jaunmuktane Z, Mead S, Ellis M, Wadsworth JDF, Nicoll AJ, Kenny J, et al. Evidence for human transmission of amyloid- $\beta$ pathology and cerebral amyloid angiopathy. Nature. 2015 Sep 10; 525(7568):247-50. http://dx.doi.org/10.1038/nature15369

11. Jucker M, Walker LC. Self-propagation of pathogenic protein aggregates in neurodegenerative diseases. Nature. 2013 Sep 5;501(7465):45-51. http://dx.doi.org/10.1038/nature12481

12. Hardy JA, Higgins GA. Alzheimer's disease: The amyloid cascade hypothesis. Science. 1992 Apr 10; 256(5054):184-5. http://dx.doi.org/10.1126/science.1566067

13. Selkoe DJ, Hardy J. The amyloid hypothesis of Alzheimer's disease at 25 years. EMBO Mol Med. 2016 Jun;8(6):595-608. http://dx.doi.org/10.15252/emmm.201606210

14. He Z, Guo JL, McBride JD, Narasimhan S, Kim H, Changolkar L, et al. Amyloid- $\beta$ plaques enhance Alzheimer's brain tau-seeded pathologies by facilitating neuritic plaque tau aggregation. Nat Med. 2018 Jan 4;24(1):29-38. http://dx.doi.org/10.1038/nm.4443

15. Molinuevo JL, Ayton S, Batrla R, Bednar MM, Bittner T, Cummings J, et al. Current state of Alzheimer's fluid biomarkers. Acta Neuropathol. 2018 Dec 28;136(6):821-53. http://dx.doi.org/10.1007/ s00401-018-1932-x

16. Sanabria-Castro A, Alvarado-Echeverría I, Monge-Bonilla C. Molecular pathogenesis of Alzheimer's disease: An update. Ann Neurosci. 2017 May;24(1):46-54. http://dx.doi.org/10.1159/000464422

17. Salobrar-García E, Ramírez AI, de Hoz R, Rojas P, Salazar JJ, Rojas B, et al. Chapter 15: The impact of the eye in dementia: The eye and its role in diagnosis and follow up. In: Update on dementia. In Tech; 2016. ISBN 978-953-51-4833-3. http://dx.doi.org/10.5772/64490. Available from: http://www. intechopen.com/books/update-on-dementia/the-impact-of-the-eye-in-dementia-the-eye-and-its-rolein-diagnosis-and-follow-up

18. London A, Benhar I, Schwartz M. The retina as a window to the brain-from eye research to CNS disorders. Nat Rev. 2013;9(1):44-53. http://dx.doi.org/10.1038/nrneurol.2012.227

19. Ramirez AIAI, de Hoz R, Salobrar-Garcia E, Salazar JJJJ, Rojas B, Ajoy D, et al. The role of microglia in retinal neurodegeneration: Alzheimer's disease, Parkinson, and glaucoma. Front Aging Neurosci. 2017 Jul 6;9:214. http://dx.doi.org/10.3389/fnagi.2017.00214

20. MacCormick IJ, Czanner G, Faragher B. Developing retinal biomarkers of neurological disease: An analytical perspective. Biomark Med. 2015;9(7):691-701. http://dx.doi.org/10.2217/bmm.15.17

21. Garcia-Martin ES, Rojas B, Ramirez AI, de Hoz R, Salazar JJ, Yubero R, et al. Macular thickness as a potential biomarker of mild Alzheimer's disease. Ophthalmology. 2014;121(5):1149-51. http:// dx.doi.org/10.1016/j.ophtha.2013.12.023

22. Maldonado RSRS, Mettu P, El-Dairi M, Bhatti MTT. The application of optical coherence tomography in neurologic diseases. Neurol Clin Pract. 2015;5(5):460-9. http://dx.doi.org/10.1212/ CPJ.0000000000000187

23. Salobrar-Garcia E, Garcia Y, Lostao C, Jañez L, de Hoz R, Rojas B, et al. Maculopapillary analysis in the posterior pole in patients with mild Alzheimer's disease. Acta Ophthalmol. 2016;94:S256. http:// dx.doi.org/10.1111/j.1755-3768.2016.0372 
24. Salobrar-Garcia E, Hoyas I, Leal M, de Hoz R, Rojas B, Ramirez AI, et al. Analysis of retinal peripapillary segmentation in early Alzheimer's disease patients. Biomed Res Int. 2015 Oct 18;2015:1-8. http://dx.doi.org/10.1155/2015/636548

25. Salobrar-Garcia E, Leal M, Hoyas I, Salazar JJ, Ramirez AI, de Hoz R, et al. Early changes in mild Alzheimer's disease in the neuroretinal rim segmentation. Acta Ophthalmol. 2016;94:S256. http:// dx.doi.org/10.1111/j.1755-3768.2016.0449

26. Ramachandran VS. editor. Encyclopedia of the human brain. San Diego, CA: Academic Press; 2002;3:183-200.

27. Hinton DR, Sadun AA, Blanks JC, Miller CA. Optic-nerve degeneration in Alzheimer's disease. N Engl J Med. 1986 Aug 21;315(8):485-7. http://dx.doi.org/10.1056/NEJM198608213150804

28. Blanks JC, Torigoe Y, Hinton DR, Blanks RHI. Retinal pathology in Alzheimer's disease. I. Ganglion cell loss in foveal/parafoveal retina. Neurobiol Aging. 1996;17(3):377-84. http://dx.doi.org/ 10.1016/0197-4580(96)00010-3

29. Blanks JC, Schmidt SY, Torigoe Y, Porrello K V, Hinton DR, Blanks RHI. Retinal pathology in Alzheimer's disease. II. Regional neuron loss and glial changes in GCL. Neurobiol Aging. 1996;17(3):385-95. http://dx.doi.org/10.1016/0197-4580(96)00009-7

30. Paquet C, Boissonnot M, Roger F, Dighiero P, Gil R, Hugon J. Abnormal retinal thickness in patients with mild cognitive impairment and Alzheimer's disease. Neurosci Lett. 2007;420(2):97-9. http:// dx.doi.org/10.1016/j.neulet.2007.02.090

31. Iseri PK, Altinas Ö, Tokay T, Yüksel N. Relationship between cognitive impairment and retinal morphological and visual functional abnormalities in Alzheimer disease. J Neuro Ophthalmol. 2006;26(1):18. http://dx.doi.org/10.1097/01.wno.0000204645.56873.26

32. Ferrari L, Huang SC, Magnani G, Ambrosi A, Comi G, Leocani L. Optical coherence tomography reveals retinal neuroaxonal thinning in frontotemporal dementia as in Alzheimer's disease. J Alzheimers Dis. 2017;56(3):1101-7. http://dx.doi.org/10.3233/JAD-160886

33. Ko F, Muthy ZA, Gallacher J, Sudlow C, Rees G, Yang Q, et al. Association of retinal nerve fiber layer thinning with current and future cognitive decline: A study using optical coherence tomography. JAMA Neurol. 2018 Oct 1;75(10):1198-205. http://dx.doi.org/10.1001/ jamaneurol.2018.1578

34. Valenti DA. Neuroimaging of retinal nerve fiber layer in AD using optical coherence tomography. Neurology. 2007;69(10):1060. http://dx.doi.org/10.1212/01.wnl.0000280584.64363.83

35. Kesler A, Vakhapova V, Korczyn AD, Naftaliev E, Neudorfer M. Retinal thickness in patients with mild cognitive impairment and Alzheimer's disease. Clin Neurol Neurosurg. 2011;113(7):523-6. http:// dx.doi.org/10.1016/j.clineuro.2011.02.014

36. Moreno-Ramos T, Benito-León J, Villarejo A, Bermejo-Pareja F. Retinal nerve fiber layer thinning in dementia associated with Parkinson's disease, dementia with lewy bodies, and Alzheimer's disease. J Alzheimer's Dis. 2013;34(3):659-64. http://dx.doi.org/10.3233/JAD-121975

37. He XF, Liu YT, Peng C, Zhang F, Zhuang S, Zhang JS. Optical coherence tomography assessed retinal nerve fiber layer thickness in patients with Alzheimer's disease: A meta-analysis. Int J Ophthalmol. 2012;5(3):401-5.

38. Parisi V, Restuccia R, Fattapposta F, Mina C, Bucci MG, Pierelli F. Morphological and functional retinal impairment in Alzheimer's disease patients. Clin Neurophysiol. 2001;112(10):1860-7. http://dx.doi. org/10.1016/S1388-2457(01)00620-4

39. Lu Y, Li Z, Zhang X, Ming B, Jia J, Wang R, et al. Retinal nerve fiber layer structure abnormalities in early Alzheimer's disease: Evidence in optical coherence tomography. Neurosci Lett. 2010;480(1): 69-72. http://dx.doi.org/10.1016/j.neulet.2010.06.006

40. Moschos M, Markopoulos I, Chatziralli I, Rouvas A, Papageorgiou SG, Ladas I, et al. Structural and functional impairment of the retina and optic nerve in Alzheimer's disease. Curr Alzheimer Res. 2012;9(7):782-8. http://dx.doi.org/10.2174/156720512802455340

41. Cunha LP, Lopes LC, Costa-Cunha LVFVF, Costa CF, Pires LAA, Almeida ALM, et al. Macular thickness measurements with frequency domain-OCT for quantification of retinal neural loss and its correlation with cognitive impairment in Alzheimer's disease. PLoS One. 2016;11(4):e0153830. http://dx.doi. org/10.1371/journal.pone.0153830 
42. Williams PA, Thirgood RA, Oliphant H, Frizzati A, Littlewood E, Votruba M, et al. Retinal ganglion cell dendritic degeneration in a mouse model of Alzheimer's disease. Neurobiol Aging. 2013;34(7): 1799-806. http://dx.doi.org/10.1016/j.neurobiolaging.2013.01.006

43. Liu B, Rasool S, Yang Z, Glabe CG, Schreiber SS, Ge J, et al. Amyloid-peptide vaccinations reduce $\beta$-amyloid plaques but exacerbate vascular deposition and inflammation in the retina of Alzheimer's transgenic mice. Am J Pathol. 2009;175(5):2099-110. http://dx.doi.org/10.2353/ajpath.2009.090159

44. Koronyo Y, Biggs D, Barron E, Boyer DS, Pearlman JA, Au WJ, et al. Retinal amyloid pathology and proof-of-concept imaging trial in Alzheimer's disease. JCI Insight. 2017;2(16):pii: 93621. http:// dx.doi.org/10.1172/jci.insight.93621

45. Guo L, Salt TE, Luong V, Wood N, Cheung W, Maass A, et al. Targeting amyloid-beta in glaucoma treatment. Proc Natl Acad Sci. 2007 Aug 14;104(33):13444-9. http://dx.doi.org/10.1073/ pnas.0703707104

46. Du LY, Chang LYL, Ardiles AO, Tapia-Rojas C, Araya J, Inestrosa NC, et al. Alzheimer's diseaserelated protein expression in the retina of Octodon degus. PLoS One. 2015;10(8):1-17. http://dx.doi. org/10.1371/journal.pone.0135499

47. La Morgia C, Ross-Cisneros FN, Koronyo Y, Hannibal J, Gallassi R, Cantalupo G, et al. Melanopsin retinal ganglion cell loss in Alzheimer disease. Ann Neurol. 2016;79(1):90-109. http://dx.doi. org/10.1002/ana. 24548

48. Sadun AA, Schaechter JD, Smith LE. A retinohypothalamic pathway in man: Light mediation of circadian rhythms. Brain Res. 1984;302(2):371-7. http://dx.doi.org/10.1016/0006-8993(84)90252-X

49. Hattar S, Liao HW, Takao M, Berson DM, Yau KW. Melanopsin-containing retinal ganglion cells: Architecture, projections, and intrinsic photosensitivity. Science. 2002 Feb 8;295(5557):1065-70. http://dx.doi.org/10.1126/science.1069609

50. Berson DM, Dunn FA, Takao M. Phototransduction by retinal ganglion cells that set the circadian clock. Science. 2002 Feb 8;295(5557):1070-3. http://dx.doi.org/10.1126/science.1067262

51. Sand A, Schmidt TM, Kofuji P. Diverse types of ganglion cell photoreceptors in the mammalian retina. Prog Retin Eye Res. 2012 Jul;31(4):287-302. http://dx.doi.org/10.1016/j.preteyeres.2012.03.003

52. Oliveira-Souza FG, DeRamus ML, van Groen T, Lambert AE, Bolding MS, Strang CE. Retinal changes in the Tg-SwDI mouse model of Alzheimer's disease. Neuroscience. 2017;354:43-53. http://dx.doi. org/10.1016/j.neuroscience.2017.04.021

53. Dagnelie G. Age-related psychophysical changes and low vision. Invest Ophthalmol Vis Sci. 2013;54(14):ORSF88-93. http://dx.doi.org/10.1167/iovs.13-12934

54. Mapstone M, Dickerson K, Duffy CJ. Distinct mechanisms of impairment in cognitive ageing and Alzheimer's disease. Brain. 2008;131(Pt 6):1618-29. http://dx.doi.org/10.1093/brain/awn064

55. Prvulovic D, Hubl D, Sack AT, Melillo L, Maurer K, Frölich L, et al. Functional imaging of visuospatial processing in Alzheimer's disease. Neuroimage. 2002;17(3):1403-14. http://dx.doi.org/10.1006/ nimg.2002.1271

56. Rizzo M, Anderson SW, Dawson J, Nawrot M. Vision and cognition in Alzheimer's disease. Neuropsychologia. 2000;38(8):1157-69. http://dx.doi.org/10.1016/S0028-3932(00)00023-3

57. Tippett WJ, Black SE. Regional cerebral blood flow correlates of visuospatial tasks in Alzheimer's disease. J Int Neuropsychol Soc. 2008;14(06):1034-45. http://dx. doi.org/10.1017/S1355617708081241

58. Cronin-Golomb A, Sugiura R, Corkin S, Growdon JH. Incomplete achromatopsia in Alzheimer's disease. Neurobiol Aging. 1993;14(5):471-7. http://dx.doi.org/10.1016/0197-4580(93)90105-K

59. Kurylo DD, Corkin S, Dolan RP, Rizzo JF, Parker SW, Growdon JH. Broad-band visual capacities are not selectively impaired in Alzheimer's disease. Neurobiol Aging. 1994;15(3):305-11. http://dx.doi. org/10.1016/0197-4580(94)90025-6

60. Rizzo M, Anderson SW, Dawson J, Myers R, Ball K. Visual attention impairments in Alzheimer's disease. Neurology. 2000;54(10):1954-9. http://dx.doi.org/10.1212/WNL.54.10.1954

61. Vighetto A. Towards an earlier diagnosis of Alzheimer's disease presenting with visuospatial disorders (posterior cortical atrophy). Rev Neurol (Paris). 2013 Oct 1;169(10):687-94. http://dx.doi. org/10.1016/j.neurol.2013.08.001

62. Gouras P. Color vision [Internet]. Webvision: The Organization of the Retina and Visual System. University of Utah Health Sciences Center; 1995. 
63. Laycock R, Crewther SG, Crewther DP. A role for the "magnocellular advantage" in visual impairments in neurodevelopmental and psychiatric disorders. Neurosci Biobehav Rev. 2007;31(3):363-76. http:// dx.doi.org/10.1016/j.neubiorev.2006.10.003

64. Martin PR, White AJR, Goodchild AK, Wilder HD, Sefton AE. Evidence that blue-on cells are part of the third geniculocortical pathway in primates. Eur J Neurosci. 1997;9(7):1536-41. http://dx.doi. org/10.1111/j.1460-9568.1997.tb01509.x

65. Solomon SG, Lennie P. The machinery of colour vision. Nat Rev Neurosci. 2007;8(4):276-86. http:// dx.doi.org/10.1038/nrn2094

66. Neargarder SA, Stone ER, Cronin-Golomb A, Oross S. The impact of acuity on performance of four clinical measures of contrast sensitivity in Alzheimer's disease. J Gerontol B Psychol Sci Soc Sci. 2003;58(1):P54-62. http://dx.doi.org/10.1093/geronb/58.1.P54

67. Dargent-Molina P, Hays M, Breart G. Sensory impairments and physical disability in aged women living at home. Int J Epidemiol. 1996;25(3):621-9. http://dx.doi.org/10.1093/ije/25.3.621

68. Wong SH, Plant GT. How to interpret visual fields. Pract Neurol. 2015;15(5). http://dx.doi. org/10.1136/practneurol-2015-001155

69. Cooper SA, Metcalfe RA. Assess and interpret the visual fields at the bedside. Pract Neurol. 2009 Dec;9(6):324-34. http://dx.doi.org/10.1136/jnnp.2009.193920

70. Viggiano MP, Gori G, Zaccara G, Righi S, Vannucci M, Giovannelli F. Category-specific visual identification of filtered objects in Alzheimer's disease. Arch Gerontol Geriatr. 2007;44(2):125-39. http:// dx.doi.org/10.1016/j.archger.2006.04.003

71. Hayes T, Morrone MC, Burr DC. Recognition of positive and negative bandpass-filtered images. Perception. 1986 Oct 25;15(5):595-602. http://dx.doi.org/10.1068/p150595

72. Braje WL, Tjan BS, Legge GE. Human efficiency for recognizing and detecting low-pass filtered objects. Vision Res. 1995 Nov;35(21):2955-66. http://dx.doi.org/10.1016/0042-6989(95)00071-7

73. Hughes HC, Nozawa G, Kitterle F. Global precedence, spatial frequency channels, and the statistics of natural images. J Cogn Neurosci. 1996 Jul;8(3):197-230. http://dx.doi.org/10.1162/ jocn.1996.8.3.197

74. Parker DM, Lishman JR, Hughes J. Role of coarse and fine spatial information in face and object processing. J Exp Psychol Hum Percept Perform. 1996 Dec;22(6):1448-66. http://dx.doi. org/10.1037//0096-1523.22.6.1448

75. Olds ES, Engel SA. Linearity across spatial frequency in object recognition. Vision Res. 1998 Jul;38(14):2109-18. http://dx.doi.org/10.1016/S0042-6989(97)00393-3

76. Huang D, Swanson EA, Lin CP, Schuman JS, Stinson WG, Chang W, et al. Optical coherence tomography. Opt Coher Tomogr. 1991 Nov 22;254(5035):1178-81. http://dx.doi.org/10.1126/ science. 1957169

77. Bandello F, Souied E, Querques G. OCT angiography in retinal and macular diseases. Bandello F, Souied E, Querques G, editors. New York: Karger Medical and Scientific Publishers; 2016. http:// dx.doi.org/10.1159/isbn.978-3-318-05830-7

78. Huang D, Lumbroso B, Jia Y, Waheed N. Optical coherence tomography angiography of the eye. USA: SLACK Incorporated; 2018.

79. Lakshminarayanan V, Lagrave J, Kean ML, Dick M, Shankle R. Vision in dementia: Contrast effects. Neurol Res. 1996;18(1):9-15. http://dx.doi.org/10.1080/01616412.1996.11740369

80. Schlotterer G, Moscovitch M, Crapper-McLachlan D. Visual processing deficits as assessed by spatial frequency contrast sensitivity and backward masking in normal ageing and Alzheimer's disease. Brain. 1984;107(1):309-25. http://dx.doi.org/10.1093/brain/107.1.309

81. Wright CE, Drasdo N, Harding GFAA. Pathology of the optic nerve and visual association areas information given by the flash and pattern visual evoked potential, and the temporal and spatial contrast sensitivity function. Brain. 1987 Feb;110(1):107-20. http://dx.doi.org/10.1093/brain/110.1.107

82. Levine DN, Lee JM, Fisher CM. The visual variant of Alzheimer's disease A clinicopathologic case study. Neurology. 1993;43(2):305. http://dx.doi.org/10.1212/WNL.43.2.305

83. Martinelli V, Locatelli T, Comi G, Lia C, Alberoni M, Bressi S, et al. Pattern Visual Evoked Potential Mapping in Alzheimers Disease Correlations with Visuospatial Impairment. Dement Geriatr Cogn Disord. 1996;7(2):63-8. http://dx.doi.org/10.1159/000106855 
84. Cronin-Golomb A, Corkin S, Rizzo JF, Cohen J, Growdon JH, Banks KS. Visual dysfunction in Alzheimer's disease: Relation to normal aging. Ann Neurol. 1991;29(1):41-52. http://dx.doi. org/10.1002/ana.410290110

85. Mendez MF, Tomsak RL, Remler B. Disorders of the visual system in Alzheimer's disease. J Neuro Ophthalmol. 1990;10(1):62-9.

86. Rizzo M, Nawrot M. Perception of movement and shape in Alzheimer's disease. Brain. 1998;121(12):2259-70. http://dx.doi.org/10.1093/brain/121.12.2259

87. Murgatroyd C, Prettyman R. An investigation of visual hallucinosis and visual sensory status in dementia. Int J Geriatr Psychiatry. 2001;16(7):709-13. http://dx.doi.org/10.1002/gps.426

88. Chapman FM, Dickinson J, McKeith I, Ballard C. Association among visual hallucinations, visual acuity, and specific eye pathologies in Alzheimer's disease: Treatment implications. Am J Psychiatry. 1999;156(12):1983-5.

89. Kaeser P-F, Ghika J, Borruat F-X. Visual signs and symptoms in patients with the visual variant of Alzheimer disease. BMC Ophthalmol. 2015 Dec 30;15(1):65. http://dx.doi.org/10.1186/ s12886-015-0060-9

90. Ward ME, Gelfand JM, Lui L-Y, Ou Y, Green AJ, Stone K, et al. Reduced contrast sensitivity among older women is associated with increased risk of cognitive impairment. Ann Neurol. 2018 Apr;83(4):730-8. http://dx.doi.org/10.1002/ana.25196

91. Marmor MF. Contrast sensitivity versus visual acuity in retinal disease. Br J Ophthalmol. 1986 Jul;70(7):553-9. http://dx.doi.org/10.1136/bjo.70.7.553

92. Trick GL, Barris MC, Bickler-Bluth M. Abnormal PERG's in patients with senile dementia of the Alzheimer type. Ann Neurol. 1989;26:226-31. http://dx.doi.org/10.1002/ana.410260208

93. Salobrar-Garcia E, De Hoz R, Rojas B, Ramirez AIAI, Salazar JJJJ, Yubero R, et al. Ophthalmologic psychophysical tests support OCT findings in mild Alzheimer's disease. J Ophthalmol. 2015;2015:736949, 1-10. http://dx.doi.org/10.1155/2015/736949

94. Cronin-Golomb A, Rizzo JF, Corkin S, Growdon JH. Visual function in Alzheimer's disease and normal aging. Ann N Y Acad Sci. 1991;640:28-35. http://dx.doi.org/10.1111/j.1749-6632.1991.tb00186.x

95. Sadun AA, Borchert M, DeVita E, Hinton DR, Bassi CJ. Assessment of visual impairment in patients with Alzheimer's disease. Am J Ophthalmol. 1987;104(15):113-20. http://dx.doi. org/10.1016/0002-9394(87)90001-8

96. Bassi CJ, Solomon K, Young D. Vision in aging and dementia. Optom Vis Sci. 1993;70(10):809-13. http://dx.doi.org/10.1097/00006324-199310000-00005

97. Gilmore GC, Levy JA. Spatial contrast sensitivity in Alzheimer's disease: A comparison of two methods. Optom Vis Sci. 1991;68(10):790-4. http://dx.doi.org/10.1097/00006324-199110000-00006

98. Gilmore GC, Whitehouse PJ. Contrast sensitivity in Alzheimer's disease: A 1-year longitudinal analysis. Optom Vis Sci. 1995;72(2):83-91. http://dx.doi.org/10.1097/00006324-199502000-00007

99. Crow RW, Levin LB, LaBree L, Rubin R, Feldon SE. Sweep visual evoked potential evaluation of contrast sensitivity in Alzheimer's dementia. Invest Ophthalmol Vis Sci. 2003;44(2):875-8. http://dx.doi. org/10.1167/iovs.01-1101

100. Hutton JT, Morris JL, Elias JW, Poston JN. Contrast sensitivity dysfunction in Alzheimer's disease. Neurology. 1993;43(11):2328. http://dx.doi.org/10.1212/WNL.43.11.2328

101. Baker DR, Mendez MF, Townsend JC, Ilsen PF, Bright DC. Optometric management of patients with Alzheimer's disease. J Am Optom Assoc. 1997;68(8):483-94.

102. Cronin-Golomb A, Gilmore GC, Neargarder S, Morrison SR, Laudate TM. Enhanced stimulus strength improves visual cognition in aging and Alzheimer's disease. Cortex. 2007;43(7):952-66. http://dx.doi.org/10.1016/S0010-9452(08)70693-2

103. Risacher SL, WuDunn D, Pepin SM, MaGee TR, McDonald BC, Flashman LA, et al. Visual contrast sensitivity in Alzheimer's disease, mild cognitive impairment, and older adults with cognitive complaints. Neurobiol Aging. 2013;34(4):1133-44. http://dx.doi.org/10.1016/j.neurobiolaging.2012.08.007

104. Cerquera-Jaramillo MA, Nava-Mesa MO, González-Reyes RE, Tellez-Conti C, de-la-Torre A. Visual features in Alzheimer's disease: From basic mechanisms to clinical overview. Neural Plast. 2018 Oct 14; 2018:1-21. http://dx.doi.org/10.1155/2018/2941783

105. Trick GL, Trick LR, Morris P, Wolf M. Visual field loss in senile dementia of the Alzheimer's type. Neurology. 1995;45(1):68-74. http://dx.doi.org/10.1212/WNL.45.1.68 
106. Armstrong RA. Visual field defects in Alzheimer's disease patients may reflect differential pathology in the primary visual cortex. Optom Vis Sci. 1996;73(11):677. http://dx.doi.org/10.1097/ 00006324-199611000-00001

107. Millington R, James-Galton M, Maia Da Silva MN, Plant GT, Bridge H. Lateralized occipital degeneration in posterior cortical atrophy predicts visual field deficits. Neuroimage Clin. 2017 Jan 17;14: 242-9. http://dx.doi.org/10.1016/j.nicl.2017.01.012

108. Shuren J, Heilman KM. Visual field loss in Alzheimer's disease. J Am Geriatr Soc. 1993;41(10):1114-15. http://dx.doi.org/10.1111/j.1532-5415.1993.tb06461.x

109. Whittaker KW, Burdon MA, Shah P. Visual field loss and Alzheimer's disease. Eye. 2002;16(2):206-8. http://dx.doi.org/10.1038/sj/eye/6700037

110. Salamone G, Di Lorenzo C, Mosti S, Lupo F, Cravello L, Palmer K, et al. Color discrimination performance in patients with Alzheimer's disease. Dement Geriatr Cogn Disord. 2009;27(6):501-7. http:// dx.doi.org/10.1159/000218366

111. Wood S, Mortel KF, Hiscock M, Breitmeyer BG, Caroselli JS. Adaptive and maladaptive utilization of color cues by patients with mild to moderate Alzheimer's disease. Arch Clin Neuropsychol. 1997;12(5):483-9. http://dx.doi.org/10.1093/arclin/12.5.483

112. Massoud F, Chertkow H, Whitehead V, Overbury O, Bergman H. Word-reading thresholds in Alzheimer disease and mild memory loss: A pilot study. Alzheimer Dis Assoc Disord. 2002;16(1): 31-9. http://dx.doi.org/10.1097/00002093-200201000-00005

113. Cronin-Golomb A, Corkin S, Growdon JH. Visual dysfunction predicts cognitive deficits in Alzheimer's disease. Optom Vis Sci. 1995;72(3):168-76. http://dx.doi.org/10.1097/00006324-199503000-00004

114. Pache M, Smeets CHW, Gasio PF, Savaskan E, Flammer J, Wirz-Justice A, et al. Colour vision deficiencies in Alzheimer's disease. Age Ageing. 2003;32(4):422-6. http://dx.doi.org/10.1093/ageing/32.4.422

115. Pelak VS, Hills W. Vision in Alzheimer's disease: A focus on the anterior afferent pathway. Neurodegener Dis Manag. 2018 Feb 23;8(1):49-67. http://dx.doi.org/10.2217/nmt-2017-0030

116. Polo V, Rodrigo MJ, Garcia-Martin E, Otin S, Larrosa JM, Fuertes MI, et al. Visual dysfunction and its correlation with retinal changes in patients with Alzheimer's disease. Eye (Lond). 2017;31(7): 1034-41. http://dx.doi.org/10.1038/eye.2017.23

117. Rami L, Serradell M, Bosch B, Villar A, Molinuevo JL. Perception digital test (PDT) for the assessment of incipient visual disorder in initial Alzheimer's disease. Neurologia. 2007;22(6):342-7.

118. Ong Y-L, Ong Y-T, Ikram MK, Chen CLH, Wong TY, Cheung CY. Potential applications of spectraldomain optical coherence tomography (SD-OCT) in the study of Alzheimer's disease. Proc Singapore Heal Vol. 2014;23(1):74. http://dx.doi.org/10.1177/201010581402300112

119. Simao LM. The contribution of optical coherence tomography in neurodegenerative diseases. Curr Opin Ophthalmol. 2013;24(6):521-7. http://dx.doi.org/10.1097/ICU.0000000000000000

120. Berisha F, Feke GT, Trempe CL, McMeel JW, Schepens CL. Retinal abnormalities in early Alzheimer's disease. Invest Ophthalmol Vis Sci. 2007;48(5):2285-9. http://dx.doi.org/10.1167/iovs.06-1029

121. Kromer R, Serbecic N, Hausner L, Aboul-enein F, Froelich L, Beutelspacher S. Detection of retinal nerve fiber layer defects in Alzheimer's disease using SD-OCT. Name Front Psychiatry. 2014;5:22. http://dx.doi.org/10.3389/fpsyt.2014.00022

122. Chi Y, Wang YH, Yang L. The investigation of retinal nerve fiber loss in Alzheimer's disease. Zhonghua Yan Ke Za Zhi. 2010;46(2):134-9.

123. Shen Y, Shi Z, Jia R, Zhu Y, Cheng Y, Feng W, et al. The attenuation of retinal nerve fiber layer thickness and cognitive deterioration. Front Cell Neurosci. 2013;7(September):1-7. http://dx.doi. org/10.3389/fncel.2013.00142

124. Kirbas S, Turkyilmaz K, Anlar O, Tufekci A, Durmus M. Retinal nerve fiber layer thickness in patients with Alzheimer disease. J Neuro Ophthalmol. 2013;33(1):58-61. http://dx.doi.org/10.1097/ WNO.0b013e318267fd5f

125. Bayhan HA, Aslan Bayhan S, Celikbilek A, Tanık N, Gürdal C, Tanik N, et al. Evaluation of the chorioretinal thickness changes in Alzheimer's disease using spectral-domain optical coherence tomography. Clin Experiment Ophthalmol. 2014;43(2):145-51. http://dx.doi.org/10.1111/ceo.12386

126. Oktem EO, Derle E, Kibaroglu S, Oktem C, Akkoyun I, Can U. The relationship between the degree of cognitive impairment and retinal nerve fiber layer thickness. Neurol Sci. 2015;36(7):1141-6. http:// dx.doi.org/10.1007/s10072-014-2055-3. http://dx.doi.org/10.1007/s10072-014-2055-3 
127. Chan VTT, Sun Z, Tang S, Chen LJ, Wong A, Tham CC, et al. Spectral-domain OCT measurements in Alzheimer's disease. Ophthalmology. 2019 Apr;126(4):497-510. http://dx.doi.org/10.1016/j. ophtha.2018.08.009

128. Sánchez D, Castilla-Marti M, Rodríguez-Gómez O, Valero S, Piferrer A, Martínez G, et al. Usefulness of peripapillary nerve fiber layer thickness assessed by optical coherence tomography as a biomarker for Alzheimer's disease. Sci Rep. 2018 Dec 5;8(1):16345. http://dx.doi.org/10.1038/s41598-018-34577-3

129. Coppola G, Di Renzo A, Ziccardi L, Martelli F, Fadda A, Manni G, et al. Optical coherence tomography in Alzheimer's disease: A meta-analysis. PLoS One. 2015;10(8):1-14. http://dx.doi.org/10.1371/ journal.pone. 0134750

130. Thomson KL, Yeo JM, Waddell B, Cameron JR, Pal S. A systematic review and meta-analysis of retinal nerve fiber layer change in dementia, using optical coherence tomography. Alzheimers Dement. 2015;1(2):136-43. http://dx.doi.org/10.1016/j.dadm.2015.03.001

131. Krasodomska K, Lubiński W, Potemkowski A, Honczarenko K. Pattern electroretinogram (PERG) and pattern visual evoked potential (PVEP) in the early stages of Alzheimer's disease. Doc Ophthalmol. 2010;121(2):111-21. http://dx.doi.org/10.1016/j.dadm.2015.03.001

132. Justino L, Kergoat M-J, Bergman H, Chertkow H, Robillard A, Kergoat H. Neuroretinal function is normal in early dementia of the Alzheimer type. Neurobiol Aging. 2001;22(4):691-5. http://dx.doi. org/10.1016/S0197-4580(01)00234-2

133. Parisi V. Correlation between morphological and functional retinal impairment in patients affected by ocular hypertension, glaucoma, demyelinating optic neuritis and Alzheimer's disease. Semin Ophthalmol. 2003 Jan 2;18(2):50-7. http://dx.doi.org/10.1076/soph.18.2.50.15855

134. Uchida A, Pillai JA, Bermel R, Bonner-Jackson A, Rae-Grant A, Fernandez H, et al. Outer retinal assessment using spectral-domain optical coherence tomography in patients with Alzheimer's and Parkinson's disease. Invest Ophthalmol Vis Sci. 2018 Jun 1;59(7):2768-77. http://dx.doi.org/10.1167/ iovs. $17-23240$

135. Santos CY, Johnson LN, Sinoff SE, Festa EK, Heindel WC, Snyder PJ. Change in retinal structural anatomy during the preclinical stage of Alzheimer's disease. Alzheimer's Dement (Amsterdam, Netherlands). 2018;10:196-209. http://dx.doi.org/10.1016/j.dadm.2018.01.003

136. Spaide RF, Curcio CA. Anatomical correlates to the bands seen in the outer retina by optical coherence tomography: Literature review and model. Retina. 2011 Sep;31(8):1609-19. http://dx.doi. org/10.1097/IAE.0b013e3182247535

137. Staurenghi G, Sadda S, Chakravarthy U, Spaide RF, International Nomenclature for Optical Coherence Tomography $(\mathrm{IN} \bullet \mathrm{OCT})$ Panel. Proposed lexicon for anatomic landmarks in normal posterior segment spectral-domain optical coherence tomography: The IN•OCT consensus. Ophthalmology. 2014 Aug;121(8):1572-8. http://dx.doi.org/10.1016/j.ophtha.2014.02.023

138. Asanad S, Ross-Cisneros FN, Nassisi M, Barron E, Karanjia R, Sadun AA. The retina in Alzheimer's disease: Histomorphometric analysis of an ophthalmologic biomarker. Invest Ophthalmol Vis Sci. 2019 Apr 1;60(5):1491-500. http://dx.doi.org/10.1167/iovs.18-25966

139. Blanks JC, Hinton DR, Sadun AA, Miller CA. Retinal ganglion cell degeneration in Alzheimer's disease. Brain Res. 1989;501(2):364-72. http://dx.doi.org/10.1016/0006-8993(89)90653-7

140. Cheung CY, Ong YTLT, Hilal S, Ikram MK, Low S, Ong YTLT, et al. Retinal ganglion cell analysis using high-definition optical coherence tomography in patients with mild cognitive impairment and Alzheimer's disease. J Alzheimers Dis Retin Ganglion Cell Anal MCI AD. 2015;45(1):45-56. http:// dx.doi.org/10.3233/JAD-141659

141. Ascaso FJ, Cruz N, Modrego PJ, Lopez-Anton R, Santabárbara J, Pascual LF, et al. Retinal alterations in mild cognitive impairment and Alzheimer's disease: An optical coherence tomography study. J Neurol. 2014;261(8):1522-30. http://dx.doi.org/10.1007/s00415-014-7374-z

142. Lad EM, Mukherjee D, Stinnett SS, Cousins SW, Potter GG, Burke JR, et al. Evaluation of inner retinal layers as biomarkers in mild cognitive impairment to moderate Alzheimer's disease. Paul F, editor. PLoS One. 2018 Feb 8;13(2):e0192646. http://dx.doi.org/10.1371/journal.pone.0192646

143. Knoll B, Simonett J, Volpe NJ, Farsiu S, Ward M, Rademaker A, et al. Retinal nerve fiber layer thickness in amnestic mild cognitive impairment: Case-control study and meta-analysis. Alzheimers Dement. 2016;4:85-93. http://dx.doi.org/10.1016/j.dadm.2016.07.004

144. Mandybur TI. Cerebral amyloid angiopathy and astrocytic gliosis in Alzheimer's disease. Acta Neuropathol. 1989;78(3):329-31. http://dx.doi.org/10.1007/BF00687764 
145. Bates KA, Fonte J, Robertson TA, Martins RN, Harvey AR. Chronic gliosis triggers Alzheimer's disease-like processing of amyloid precursor protein. Neuroscience. 2002;113(4):785-96. http://dx.doi. org/10.1016/S0306-4522(02)00230-0

146. de Jong FJ, Schrijvers EMC, Ikram MK, Koudstaal PJ, de Jong PTVM, Hofman A, et al. Retinal vascular caliber and risk of dementia: The Rotterdam study. Neurology. 2011 Mar 1;76(9):816-21. http:// dx.doi.org/10.1212/WNL.0b013e31820e7baa

147. O’Bryhim BE, Apte RS, Kung N, Coble D, Van Stavern GP. Association of preclinical Alzheimer disease with optical coherence tomographic angiography findings. JAMA Ophthalmol. 2018 Nov 1; 136(11):1242-8. http://dx.doi.org/10.1001/jamaophthalmol.2018.3556

148. Bulut M, Kurtulus F, Gozkaya O, Erol MK, Cengiz A, Akidan M, et al. Evaluation of optical coherence tomography angiographic findings in Alzheimer's type dementia. Br J Ophthalmol. 2018;102(2): 233-7. http://dx.doi.org/10.1136/bjophthalmol-2017-310476

149. Jiang H, Wei Y, Shi Y, Wright CB, Sun X, Gregori G, et al. Altered macular microvasculature in mild cognitive impairment and Alzheimer disease. J Neuroophthalmol. 2018 Sep;38(3):292-8. http:// dx.doi.org/10.1097/WNO.0000000000000580

150. Yoon SP, Grewal DS, Thompson AC, Polascik BW, Dunn C, Burke JR, et al. Retinal microvascular and neurodegenerative changes in Alzheimer's disease and mild cognitive impairment compared with control participants. Ophthalmol Retina. 2019 Jun;3(6):489-99. http://dx.doi.org/10.1016/j. oret.2019.02.002

151. Gharbiya M, Trebbastoni A, Parisi F, Manganiello S, Cruciani F, D’Antonio F, et al. Choroidal thinning as a new finding in Alzheimer's disease: Evidence from enhanced depth imaging spectral domain optical coherence tomography. J Alzheimer's Dis. 2014;40(4):907-17. http://dx.doi.org/10.3233/ JAD-132039

152. Cunha JPJP, Proença R, Dias-Santos A, Melancia D, Almeida R, Águas H, et al. Choroidal thinning: Alzheimer's disease and aging. Alzheimers Dement. 2017;8:11-17. http://dx.doi.org/10.1016/j. dadm.2017.03.004

153. Trebbastoni A, Marcelli M, Mallone F, D’Antonio F, Imbriano L, Campanelli A, et al. Attenuation of choroidal thickness in patients with Alzheimer disease: Evidence from an Italian prospective study. Alzheimer Dis Assoc Disord. 2017;31(2):128-34. http://dx.doi.org/10.1097/WAD.0000000000000176

154. Dorr A, Sahota B, Chinta LV, Brown ME, Lai AY, Ma K, et al. Amyloid- $\beta$-dependent compromise of microvascular structure and function in a model of Alzheimer's disease. Brain. 2012 Oct;135(10): 3039-50. http://dx.doi.org/10.1093/brain/aws243 